\title{
ASSESSMENT OF SMALLHOLDER FARMERS' VULNERABILITY TO CLIMATE CHANGE IN OGUN STATE, NIGERIA
}

\author{
Fatoki Olalekan A.*, Adesope Adejare A., Awe Femi, \\ Oguntoye Titilayo O., Arowolo Olayinka V. \\ Department of Forest Economics and Extension Services, \\ Forestry Research Institute of Nigeria, Ibadan, Oyo State, Nigeria \\ *E-mail: gobite2002@yahoo.com \\ ORCID: 0000-0002-8131-0531
}

\begin{abstract}
This study investigated the assessment of smallholder farmers' vulnerability to climate change in Ogun State, Nigeria. A multi-stage sampling technique was used to select 150 farmers in the agricultural zones of Abeokuta, ljebu and llaro. Data were collected with the aid of well structured questionnaire from the farmers. Descriptive statistics and Principal Component Analysis (PCA) were used for the data analyzed. The average age of the respondents was 45.5 years. The majority were married with an average household size of 5 persons while a larger percentage of the respondents are involved in crop farming. The result shows that most of the farmers are aware of variations in the prevailing weather conditions of their area and floods were mostly experienced in the year 2018 and 2019 . The vulnerability indices in Ilaro, Abeokuta and ijebu ode agricultural zones were $-0.652,0.250$, and 0.303 respectively. This means that ljebu ode was the least vulnerable to climate change followed by Abeokuta while Ilaro is the most vulnerable. Therefore, the study recommends that an integrated rural development scheme aimed at increasing access to social amenities should be established by the government to strengthen the resilience of rural farmers to climate change.
\end{abstract}

\section{KEY WORDS}

Climate change, vulnerability, smallholder farmers, adaptive capacity, principal component analysis, Ogun state.

Climate change is an observed change in climate which is attributed directly or indirectly to human activities that alter the composition of the global atmosphere and which are in addition to natural variability observed over comparable time periods (IPCC, 2007). Through extreme temperature, frequent flooding and drought and increased salinity of water supply used for irrigation, climate change has become a recurrent subject of debate globally. Since Nigeria is one of the countries contributing to global warming, the vulnerability of its agricultural sector to climate change is of particular interest to policy makers because agriculture is a key sector in the economy, accounting for between 60 and $70 \%$ of the labour force and contributing between 30 and $40 \%$ of the nation's GDP (Ajetomobi et.al., 2010; Adebisi-Adelani and Oyesola, 2014). Nigeria's climate is likely to see growing shifts in temperature, rainfall, storms, and sea levels throughout the twenty-first century.

If unaddressed, these climatic challenges could throw already stressed resources such as land and water into even shorter supply. Moreover, poor responses to resource shortages could have serious negative secondary effects, including more sickness and hunger, fewer jobs, and poor economic growth which, in turn could open the door to more violence (Sylla et al., 2016). Increasing heat plus less rain is already creating drought conditions in parts of northern Nigeria and in parts of southern Nigeria, flooding caused by sea level rise is also contaminating freshwater aquifers, rivers and stock-watering points, leaving them with high salinity and more polluted with sediment and sewage. Climate change may also leave Nigeria increasingly short of at least two types of man-made resources. Sea level rise and severe weather could cause significant property loss. 
Odjugo, (2009) reported that between 1992 and 2007, wind and rainstorms alone damaged or destroyed economically productive assets worth at least $\$ 720$ million across twelve of Nigeria's thirty-six states. Poor people who depend on agriculture are the most vulnerable to climate change. Increasing crop failures and livestock deaths are already imposing high economic losses and undermining food security (Morton, 2017). More frequent droughts and increasing water scarcity may devastate large parts of the tropics and undermine irrigation and drinking water in entire communities of already poor and vulnerable people (World Bank, 2013).

The availability of agricultural products is affected by climate change directly through its effect on crop yields, crop pests and diseases, and soil fertility and water-holding properties. It is also affected by climate change indirectly through its impact on economic growth, income distribution, and agricultural demand (Adimasu and Kessler, 2016). In addition, the stability of crop yield and food supplies is negatively affected by variable weather conditions. Physical, economic, and social access to food is also affected negatively by climate change because agricultural production declines, food prices rise, and purchasing power decreases. Furthermore, climate change poses threats to food utilization through its effect on human health and the spread of diseases in geographical areas which were previously not affected. By 2080 , agricultural output in developing countries may decline by $20 \%$ due to climate change, while output in industrial countries is expected to decrease by 6\% (Morton, 2017). Also due to climate change, yields in developing countries could further decrease by $15 \%$ on the average by 2080 (FAO, 2008).

Climate change worsens the living conditions of many who are already vulnerable, particularly in developing countries like Nigeria because of the lack of assets and adequate insurance coverage. Agriculture-based livelihood systems such as small-scale rainfed farming, pastoralism, inland and coastal fishing and forest-based systems that are already vulnerable to climate change face immediate risk of increased crop failure, loss of livestock and fish stocks, increasing water scarcities and destruction of productive assets(FAO, 2008). These unfavourable conditions are likely to adversely affect the income, standard of living and health status of agrarian households. The livelihood status of agricultural firms will also be affected if methods of production become less labour-intensive as a result of climate change.

The population of Nigeria is projected to increase by more than $50 \%$ in the coming two decades (Adebisi-Adelani and Oyesola; 2014). During this period, the rural population is projected to increase by more than $25 \%$ while the agricultural component is expected to grow by a slightly lower proportion, moderated by climate change and undercapitalization of the small holder farmers. Studies that relate climate change to agricultural production in Nigeria are more of general analyses of potential impacts of climate change on crop production and animal husbandry (NEST, 2004; Adejuwon, 2006; Abiodun and Olabimpe, 2007; Adefolalu, 2007; Jagtap, 2007; Nwafor, 2007). Some of studies have also been carried out on climate change adaptation strategies, methods of mitigation as well as vulnerability to climate hazards in Northern Nigeria (Apata et. al., 2009; Ajetomobi et. al., 2010; Ayinde et. al., 2011; Odjugo, 2010; Onyeneke and Madukwe, 2010; Ozor and Cynthia, 2009; Sofoluwe et. al., 2011; Umar and Ibrahim, 2011; Adebisi-Adelani and Oyesola, 2014; Ayanlade et al., 2017). However, an extensive survey on assessment of vulnerability of smallholder farmers in southwest region of Nigeria, where climate related hazards are highly felt has not been carried out. Hence this study will help provide useful information on how small scale farmers can become resilient to the climate change effects. Consequently, this study intends to assess the vulnerability of smallholder farmers to climate change and also analyze the perception of the farmers to climate variability in the study area.

\section{MATERIALS AND METHODS OF RESEARCH}

The study area is Ogun State in Southwestern Nigeria. The state was created on February $3^{\text {rd }}, 1976$ from the old western region. It is bordered by Oyo, Ondo, Lagos, Edo and Delta States. The state lies between longitude $2^{\circ} 2^{\prime}$ and $3^{\circ} 55^{\prime}$ and latitude $7^{\circ} 0^{\prime}$ and $7^{0} 18^{\prime}$. It is 
approximately $1.9 \%\left(16,762 \mathrm{~km}^{2)}\right.$ of Nigeria's $923,219 \mathrm{~km}^{2}$ land area of which over $70 \%$ is suitable for arable crop production. It is located in the moderately hot, humid tropical climatic zone of south western Nigeria. It has a tropical climate with two distinct seasons - the rainy and the dry season. The three main vegetation types in the study area are the tropical rainforest, guinea and derived savannah. It is made up of 20 Local Government Areas spread across the four main agricultural zones of the state - Abeokuta, ljebu, Ikenne, and llaro. The overall population of the state is 3,728,098 according to the National Population Commission census report in 2006.

Data were obtained with the aid of a well structured questionnaire and personal interviews. Data collected include the socio-economic characteristics of respondents (such as age, gender, marital status, educational status, farming experience and farm size), their perception of climate variability and adaptive capacity.

The multistage sampling procedure was used to select small-holder farmers in the study area. In the first stage, 3 zones were randomly selected from the 4 agricultural development zones in the state. In the second stage, 5 blocks were selected from each of the agricultural zones resulting to fifteen 15 blocks. In the final stage, 10 smallholder farmers were randomly selected in each of the blocks, making a total of 150 respondents that were used for the study.

Descriptive statistics such as frequencies and percentages were used in the description of the socio-economic characteristics and perception of the farmers to climate change.

This was used to assess the vulnerability of small-holder farmers in Southwestern Nigeria. Vulnerability is calculated as the net effect of adaptive capacity, sensitivity and exposure.

$$
\text { Vulnerability }=(\text { adaptive capacity })-(\text { sensitivity }+ \text { exposure })
$$

It is however necessary to attach weights to the indices using the principal component analysis (PCA). The PCA is frequently used in research that is based on constructing indices for which there are no well defined weights. The use of asset-based indices for measurements of wealth across different social groups is a good example (Langyintuo 2005; Vyas and Kumaranayake 2006). As with the asset based indices for wealth comparism, there are no well-defined weights assigned to the vulnerability indices chosen for this research work. Therefore a statistical method (PCA) was employed to generate the weights.

The PCA is a technique of extracting from a set of variables the few orthogonal linear combinations of variables that most successfully capture the common information. Intuitively, the first principal component of a set of variables is a linear index of all the variables that capture the largest amount of information common to all the variables.

The PCA was carried out to obtain the component scores which were used to weight the variable in order to attach weights to the vulnerability indices using the component scores of the first principal component.

$$
\text { Vulnerability }=(\text { Adaptive capacity })-(\text { Sensitivity }+ \text { Exposure })
$$

The equation can be operationalised as follows:

$$
V=\left[\left(w A_{1}+w A_{2} \ldots \ldots w A_{n}\right)-\left(w S_{1}+w S_{2} \ldots \ldots . w S_{n}\right)-\left(w E_{1}+w E_{2} \ldots \ldots w E_{n}\right)\right]
$$

Where: $V$ is vulnerability index, $w$ is the weight obtained from first principal component scores, $A_{1}-A_{n}$ is the adaptive variable, $S_{1}-S_{n}$ is the sensitivity variables and $E_{1}-E_{n}$ is the exposure variables.

In the calculation, both exposure and sensitivity were given negative signs. The justification is that areas that are exposed to damaging climate are more sensitive to damages, assuming constant adaptive capacity (Hassan et. al., 2008). Thus, a higher net value indicates lesser vulnerability and vice versa. The next step is the attachment of weights 
to the vulnerability indices. PCA is frequently used in research that is based on constructing indices for which there are no well- defined weights.

Therefore, a standardized vulnerability index can thus be generated using:

$$
V_{j}=\sum\left[b_{i}\left(a i j-x_{i}\right)\right] / S_{i}
$$

Where: $V_{j}=$ Standardized vulnerability index for each district; $b_{i}=$ The weight scores assigned to the $(k)$ variables on the first principal components; $x_{i}=$ The mean of each of the $k$ variables;

$\mathrm{S}_{\mathrm{i}}=$ The standard deviations; aij $=$ The value of each respondent on each of the $\mathrm{k}$ variables

The first principal component of a set of variables is a linear index of all the variables that captures the largest amount of information common to all the variables.

Table 1 - Vulnerability indicators, units of measurement, and expected direction with respect to vulnerability

\begin{tabular}{|c|c|c|c|c|}
\hline $\begin{array}{l}\text { Determinants of } \\
\text { Vulnerability }\end{array}$ & $\begin{array}{l}\text { Vulnerability } \\
\text { Indicators }\end{array}$ & $\begin{array}{l}\text { Description of Each } \\
\text { Indicator Selected for } \\
\text { Analysis }\end{array}$ & Unit of Measurement & $\begin{array}{l}\text { Hypothesized Functional } \\
\text { Relationship } \\
\text { Between Indicator and } \\
\text { Vulnerability }\end{array}$ \\
\hline \multirow[t]{4}{*}{ Adaptive capacity } & Wealth & $\begin{array}{l}\text { Livestock ownership } \\
\text { Ownership of radio } \\
\text { Quality of residential } \\
\text { home } \\
\text { Non-agricultural income } \\
\text { Gift and remittance }\end{array}$ & $\begin{array}{l}\text { Percentage of total } \\
\text { population who own or have } \\
\text { access to }\end{array}$ & $\begin{array}{l}\text { The higher the percentage of } \\
\text { total population with asset } \\
\text { ownership, and access to these } \\
\text { income sources the lesser the } \\
\text { vulnerability. }\end{array}$ \\
\hline & Technology & $\begin{array}{l}\text { Access to input supply } \\
\text { Use of improved seeds }\end{array}$ & $\begin{array}{l}\text { Percentage of total } \\
\text { population } \\
\text { who have this technology } \\
\text { available on the farm }\end{array}$ & $\begin{array}{l}\text { The higher the percentage of } \\
\text { total population making use of } \\
\text { this technology, the lesser the } \\
\text { vulnerability. }\end{array}$ \\
\hline & $\begin{array}{l}\text { Infrastructures } \\
\text { and institutions }\end{array}$ & $\begin{array}{l}\text { All-weather roads } \\
\text { Health services } \\
\text { Telephone services } \\
\text { Primary and secondary } \\
\text { schools } \\
\text { Veterinary services } \\
\text { Food market } \\
\text { Microfinance }\end{array}$ & $\begin{array}{l}\text { Percentage of total } \\
\text { population within } 1-4 \\
\text { kilometers of these } \\
\text { infrastructures and } \\
\text { institutions }\end{array}$ & $\begin{array}{l}\text { The higher the percentage of } \\
\text { total population within } 1-4 \\
\text { kilometers, the lesser the } \\
\text { vulnerability. }\end{array}$ \\
\hline & Literacy rate & $\begin{array}{l}\text { Literacy rate age } 10 \\
\text { years and older }\end{array}$ & $\begin{array}{l}\text { Percentage of total } \\
\text { population within } 1-4 \\
\text { kilometres of these } \\
\text { infrastructures and } \\
\text { institutions. }\end{array}$ & $\begin{array}{l}\text { The higher the literacy rate, the } \\
\text { lesser the vulnerability. }\end{array}$ \\
\hline Sensitivity & Extreme climate & $\begin{array}{l}\text { Reduction in farm output } \\
\text { noticed in extreme } \\
\text { climatic condition in each } \\
\text { of the zones }\end{array}$ & $\begin{array}{l}\text { No of output }(\mathrm{kg}) / \text { total no of } \\
\text { required output in each } \\
\text { zone multiplied by } 100\end{array}$ & $\begin{array}{l}\text { The higher the frequency, the } \\
\text { more the vulnerability. }\end{array}$ \\
\hline Exposure & $\begin{array}{l}\text { Change } \\
\text { in climate }\end{array}$ & $\begin{array}{l}\text { Change } \\
\text { in temperature } \\
\text { Change } \\
\text { in precipitation }\end{array}$ & $\begin{array}{l}\text { Change (delta T) in degrees } \\
\text { from base value }(2011) \\
\text { Percentage change from } \\
\text { base } \\
\text { value (2011) }\end{array}$ & $\begin{array}{l}\text { Increasing temperature and } \\
\text { decreasing precipitation increase } \\
\text { vulnerability. }\end{array}$ \\
\hline
\end{tabular}

Source: Derressa et al., 2008.

\section{RESULTS AND DISCUSSION}

Socio-economic characteristics like age, gender, marital status, household size and farming experience among others were considered. As shown in Table 2, the mean age of the farmers was 45.5 years which implies that majority of the farmers were still in their economic active age. Most (78.7\%) of the respondents were married and a larger percentage $(56 \%)$ are males. Also, $7.3 \%$ of the respondent had only primary education, $28.0 \%$ had secondary education and about $18 \%$ were educated up to tertiary institution level such as colleges, polytechnics and universities. This indicates that the majority $(53.3 \%)$ of the 
farmers in the study area were literate as they have one form of formal education or the other, $46.7 \%$ had no formal education. This may have a significant impact on the vulnerability level of the farmers because education can increase awareness level and adaptability to climate extremes. Furthermore, Most (56.7\%) of the farmers were highly experienced, as they have been into farming activities for over 20 years while $43.3 \%$ had less than 20 years' experience in farming while the majority of the respondents $(60.7 \%)$ had between $1-5$ members in their households, 34.0\% had between 6-10 household members. As revealed in table 2, a large proportion of the farmers (64.0\%) majorly practice crop farming while substantial proportion (46.0\%) of them combine livestock farming with crop farming activities in the study area.

Table 2 - Distribution of Respondents by Personal Characteristics

\begin{tabular}{lll}
\hline Personal Characteristics & Frequency & Percentage (\%) \\
\hline Age & & \\
$<30$ & 13 & 8.7 \\
$31-40$ & 35 & 23.4 \\
$41-50$ & 52 & 34.6 \\
$51-60$ & 27 & 18.1 \\
Above 60 & 37 & 15.4 \\
Gender & & \\
Male & 84 & 56.0 \\
Female & 66 & 44.0 \\
Marital status & & \\
Married & 118 & 78.7 \\
Single & 18 & 12.0 \\
Widowed & 14 & 9.3 \\
Educational level & & \\
No formal education & 70 & 46.7 \\
Primary education & 11 & 7.3 \\
Secondary education & 42 & 28.0 \\
Tertiary education & 27 & 18.0 \\
Farming experience(years) & & \\
Less than 20 & 65 & 43.3 \\
More than 20 & 85 & 56.7 \\
Household size(persons) & & \\
1-5 persons & & 60.7 \\
6-10 persons & 91 & 34.0 \\
11-15persons & 51 & 4.0 \\
Above 15 & 5 & 1.3 \\
Agricultural practices & 2 & 64.0 \\
Crop farming & & 36.0 \\
Crop and Livestock & 96 & \\
\hline
\end{tabular}

Source: Field Survey, 2019.

Table 3 - Respondents Awareness of Climate Variability

\begin{tabular}{lll}
\hline Awareness & Frequency & Percentage (\%) \\
\hline Yes & 147 & 98.0 \\
No & 3 & 2.0 \\
Total & 150 & 100 \\
\hline
\end{tabular}

Source: Field Survey, 2019.

Table 3 indicates that the majority $(98.0 \%)$ of respondents claimed to be aware of variations in climatic conditions of the study area while $2 \%$ claimed to be ignorant of the variations in climatic conditions. This shows that most of the people in the study area were not ignorant of the variations in the prevailing atmospheric condition of their area.

Results indicate that $90 \%$ of the respondents claimed to have noticed extremely high temperature in 2018, while $98.7 \%$ of the respondents noticed same in 2019 as shown in table 4. This shows that majority of the farmers observed an extremely high temperature over the last two years which may have affected farming activities. The result also shows that in $2018,90.0 \%$ of the respondents noticed too much rainfall whereas $74.0 \%$ noticed too much rainfall in 2019. This indicates that floods were mostly common in 2019.

The study analyzed vulnerability based on the integrated assessment approach by making use of the vulnerability index. The direction of relationship in vulnerability indicators (i.e. their sign) was adopted from the procedure followed by Moss, Brenkert and Malone 
(2011), who assigned a negative value to sensitivity and a positive value to adaptive capacity and then calculated the vulnerability index resilience indicator. Exposure was represented by both future gradual changes in climate and the forecasted values of the probabilities of extreme events (e.g flood). Data on the forecasted probabilities of future climate extremes were not found, so a strong assumption was made that areas with higher changes in temperature and precipitation were more exposed. Variables listed under adaptive capacity were given a 141 positive value. It was also assumed that farmers with higher adaptive capacity are less sensitive to damages from climate change, given a constant level of exposure.

Table 4 - Noticed Climatic variables by the respondents in the last two years

\begin{tabular}{lllll}
\hline Climatic variables & & 2018 & Frequency & Percentage (\%) \\
\hline Extreme high temperature & Frequency & Percentage (\%) & 148 & 98.7 \\
Too much rainfall & 135 & 90.0 & 111 & 74.0 \\
High intensity sunlight & 135 & 90.0 & 107 & 89.2 \\
Too stormy rainfall & 113 & 75.3 & 82 & 68.3 \\
\hline
\end{tabular}

Source: Field Survey, 2019.

Table 5 - Vulnerability Indicators with their Corresponding Factor Scores of First Principal Component

\begin{tabular}{|c|c|}
\hline Vulnerability Indicators & Factor Scores \\
\hline Extension services & -0.066 \\
\hline Ownership of Livestock & 0.064 \\
\hline Ownership of Radio & 0.062 \\
\hline Type of House & 0.065 \\
\hline Non-agricultural income & 0.065 \\
\hline Farmer's association & 0.054 \\
\hline Raised pens & 0.046 \\
\hline All weather roads & 0.065 \\
\hline Health services & 0.059 \\
\hline Telephone Services & 0.066 \\
\hline Primary and secondary school & 0.053 \\
\hline Veterinary services & 0.056 \\
\hline Food market & 0.034 \\
\hline Micro finance & 0.024 \\
\hline Literacy Rate & -0.063 \\
\hline Water source & 0.063 \\
\hline Type of roofing materials of pen house & 0.044 \\
\hline Use of automated drinkers & 0.042 \\
\hline Extreme Climate & -0.032 \\
\hline Change in temperature & 0.063 \\
\hline Change in Precipitation & 0.065 \\
\hline Eigen value & 15.141 \\
\hline Proportion of variance & 72.10 \\
\hline Cumulative proportion & 72.10 \\
\hline
\end{tabular}

Source: Computer printout of the SPSS result.

The P.C.A was run on the indicators listed in Table 5 using the SPSS. The PCA of the data set on vulnerability indicators revealed two components with Eigen values greater than 1. These two components explained $100 \%$ of the total variation in the data set. The first principal component explained most of the variation $(72.10 \%)$ and $27.9 \%$. Based on arguments for the use of the P.C.A in constructing indices, the first principal component which explained the majority of the variation in the data set was chosen.

However, for the construction of the vulnerability indices, indicators of adaptive capacity which were positively associated with the first principal component were selected and the indicators of sensitivity and exposure which were negatively associated with the first principal component (remaining with a total of 17 indices) were also selected.

The factor scores from the principal component in Table 6 were then employed to construct indices for each agro ecological zone. For example the vulnerability index of the ljebu-ode zone was calculated as follows: The factor scores obtained from the first principal component were employed to construct indices for each of the three agricultural development zones in the study area. 
Hence, the vulnerability index for each of the zones is calculated as follows:

$$
\begin{gathered}
\text { ljebu ode zone } \\
\left(\begin{array}{c}
(0.064 * 1.02)+(0.062 * 1.08)+(0.065 * 0.73)+ \\
(0.065 *-1.0)+(0.054 * 0.26)+(0.045 * 0.05)+ \\
(0.065 * 0.68)+(0.059 * 0.41)+(0.066 * 0.94)+ \\
(0.053 * 0.22)+(0.056 * 1.14)+(0.034 * 0.22)+ \\
(0.024 * 1.03)+(0.063 * 1.00)+(0.044 * 0.00)+ \\
(0.042 * 1.14)
\end{array}\right)-(0.032 * 1.1)=0.303
\end{gathered}
$$

The calculation for the remaining zones followed the same procedure:

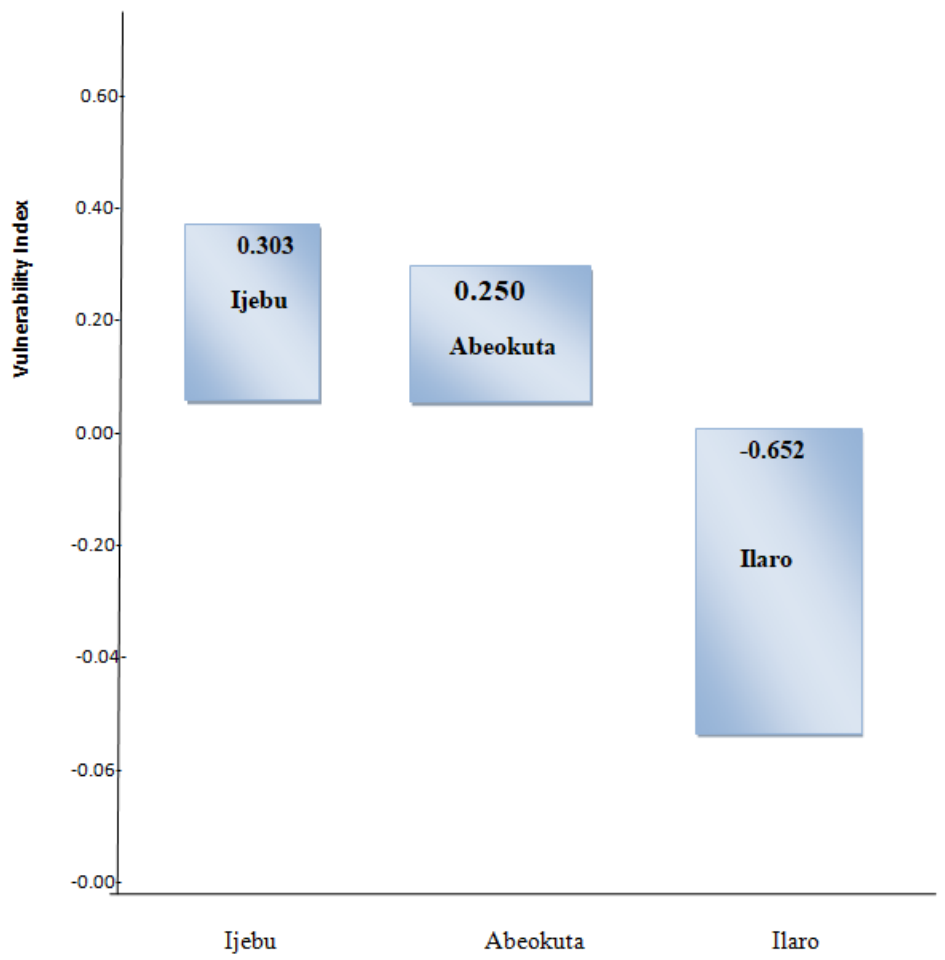

Figure 1 - Vulnerability indices of three agricultural development zones in Ogun State

Figure 1 show that the net effect of adaptive capacity, exposure and sensitivity is positive for ljebu and Abeokuta zones and negative for llaro zone. This indicates that ljebu and Abeokuta are relatively not vulnerable, while llaro was vulnerable. The vulnerability of llaro is associated with lower access to technology, infrastructural development, institutions and literacy rate, the vulnerability could also be attributed to frequency of flood.

The low vulnerability of ljebu-ode and Abeokuta could be associated with their higher access to technology, infrastructural development and literacy.

The vulnerability indices of Ilaro, Abeokuta and ijebu-ode were $-0.652,0.250$, and 0.303 respectively, indicating descending level of vulnerability. This means that ljebu-ode was the least vulnerable to climate change followed by Abeokuta, Ilaro was the most vulnerable to climate change.

\section{CONCLUSION AND RECOMMENDATIONS}

The result of the perception to climate variability indicated that most farmers in the study area were not ignorant of the variations in the prevailing atmospheric condition of their area. This result further revealed that majority of the farmers claimed to experience too much rainfall during the two years period considered which means that floods were mostly common in 2018 and 2019 in the study area. 
Results from the vulnerability assessment indicated that llaro was relatively more vulnerable to climate change. The vulnerability of llaro zone was attributed to lower access to technology, institutions and literacy rate while the vulnerability indices of ljebu and Abeokuta indicated lesser vulnerability to climate change with their higher access to technology, infrastructural development and literacy rate.

In general, small-holder farmers' vulnerability to climate change in Ogun State is highly related to poverty (loss of coping or adaptive capacity) in the zone that was indicated as vulnerable. Integrated rural development schemes aimed at increasing access to basic social amenities should be established by the government with the cooperation of the residents as this will improve adaptive capacity and thereby reduce vulnerability of small scale farmers to climate change in the study area.

\section{REFERENCES}

1. Abiodun A. and Olabimpe (2007). Agriculture in Africa: Mitigation and Adaptation to global warm up. Proceedings of the international Conference on Climate Change and Economic Sustainability held at Nnamdi Azikwe University, Enugu, Nigeria. 12 - 14 June, 2007.

2. Adebisi-Adelani, O. and Oyesola, O. (2014). Farmers' perception of the effect of climate change on tomato production in Nigeria. International Journal of Vegetable science. 20, $366-373$.

3. Adefolalu, D.O.A. (2007). Climate change and economic sustainability in Nigeria. Paper presented at the International Conference on Climate change, Nnamdi Azikwe University, Awka, 12 - 14 June, 2007.

4. Adejuwon, J.O. (2006). Food crop production in Nigeria, 11.Potential effects of climate change. Climate Resilience, 32, 229 - 245.

5. Adimassu, Z. and Kessler, A. (2016) Factors affecting Farmers' coping and adaptation strategies to perceived trends of declining rainfall and crop productivity in the central rift valley of Ethiopia. Environmental Systems Resilience. 5, 1 - 5 .

6. Ajetomobi, J. O; Abiodun, A. and Hassan, R. (2010). Economic Impact of Climate Change on Irrigated Rice Agriculture in Nigeria. Paper presented at the Joint 3rd African Association of Agricultural Economists (AAAE) and 48th Agricultural Economists Association of South Africa (AEASA) Conference, Cape Town, South Africa, September $19-23$.

7. Apata, T. G. Samuel, K. D. and Adeola, A. O. (2009). Analysis of Climate change perception and Adaptation among Arable Food Crop Farmers in south Western Nigeria paper presented at the conference of International Association of Agricultural Economists, August $16-22,2009$ at Beijing, China. PP 1 - 15

8. Ayanlade, A., Radeny, M. and Morten, J.F. (2017). Comparing Smallholder farmers' perception of climate change with meteorological data. A case study from South western Nigeria, weather and climate extremes, 15, $24-33$.

9. Ayinde, O.E; Muchie, M. and Olatunji, G.B.(2011). Effect of Climate Change on Agricultural Productivity in Nigeria: A Co-integration Model Approach. Journal of Human Ecology, 35(3): 189 - 194.

10. Deressa T., Hassan R. M., Alemu T., Yesuf M. and Ringler C. (2008). Analyzing the determinants of farmers' choice of adaptation methods and perceptions of climate change in the Nile Basin of Ethiopia. IFPRI Discussion Paper 00798.

11. Food and Agriculture Organization, (2008) Climate Change and Food Security Document. Food and Agriculture Organization of the United Nations, Rome.

12. Hassan, R and Nhemachena, C., 2008: Determinants of African farmers' strategies for adapting to climate change Multinomial choice analysis. African Journal of Resource Economics, 2(1), $83-104$.

13. International Panel on Climate Change (2007). Impact, Adaptation and Vulnerability. Contribution of Working Group I of the Intergovernmental Panel on Climate Change to the Third Assessment Report of IPCC. London: Cambridge University Press. 
14. Jagtap, S.(1995). Changes in Annual, Seasonal and, Monthly Rainfall in Nigeria and Consequences to Agriculture, Discovery and Innovation, 7(4), 311-426.

15. Langyintuo A.S. (2005). Maize production systems for Zimbabwe: Setting indicators for impact assessment and targeting. Research Project on strengthening seed marketing incentives in southern Africa to increase impact of maize breeding. International Maize and wheat improvement centre (CIMMYT), Harare, Zimbabwe.

16. Morton, J. (2017). Climate change and African agriculture: Unlocking the potential of research and advisory services. In: Nunan, F. (Ed)., In making Climate Compatible Development Happen. Routledge, 87 - 113. ISBN 978-1138657021

17. Moss, R., Brenkert, A. and Malone, E. (2001). Vulnerability to climate change, A quantitative approach. http://www.ntis.gov.html. Accessed October, 2019

18. Nigerian Environmental Study Team (2004) Regional Climate Modeling and Climate Scenarios Development in Support of Vulnerability and Adaptation Studies: Outcome of Regional Climate modeling Efforts over Nigeria, NEST, Ibadan Nigeria. PP 12-20.

19. Nwafor JC (2007). Global climate change: The driver of multiple causes of flood intensity in Sub-Saharan Africa. Paper presented at the International Conference on Climate Change and Economic Sustainability held at Nnamdi Azikiwe Uni-versity, Enugu, Nigeria, pp 67-72.

20. Odjugo, P.A. O. (2009). Quantifying the Cost of Climate Change Impact in Nigeria: Emphasis on Wind and Rainstorms, Journal of Human Ecology, 28(2): 93 - 101.

21. Odjugo, P.A. O. (2010). General Overview of Climate Change Impacts in Nigeria, Journal of Human Ecology, 29(1): 47 - 55.

22. Onyeneke, R. U. and Madukwe, D. K (2010). Adaptation Measures by Crop Farmers in the Southeast Rainforest Zone of Nigeria to Climate Change. Science World Journal. $5(1): 32-34$.

23. Ozor, N. and Cynthia, N.(2011). The role of extension in agricultural adaptation to climate change in Enugu State, Nigeria. Journal of Agricultural Extension and Rural Development $3(3): 42-50$.

24. Sofoluwe, N. A., Tijani, A.A. and Baruwa, O.I. (2011). Farmers' perception and adaptation to climate change in Osun State, Nigeria. African Journal of Agricultural Research, 6(20): 4789 - 4794.

25. Sylla, M.B., Eiguindi, N., Giorgi, F. and Wiser, D. (2016). Projected robust shift of climate zones over West Africa in response to anthropogenic climate change for late 21st century. Climate change 134, 241-253.

26. Umar H. S. and Ibrahim H. Y.(2011). Mitigating Climate Change through Organic Agriculture: A Case Study of Farmers' Participation in Organic Farming Practices in Nasarawa State, Nigeria. SATECH 4(1): $44-52$.

27. Vyas, S., and L. Kumaranayake. 2006. Constructing socio-economic status indices: How to use principal component analysis. Health Policy and Planning 21(6): 459-468.

28. World Bank (2013). Turn Down the Heat: Climate Extreme Regional Impact and Case for Resilience. A Report for the World Bank by the Potsdam Institute for Climate Impact Research and Climate Analytics, Washington DC. 